\title{
Growth, Food and Feeding Habits of Bagrus bayad and Bagrus docmac Inhibiting Muess Channel, Sharkia Province, Egypt
}

\section{EI-Drawany MA* and Elnagar WG}

Department of Zoology, Faculty of Science, Zagazig University, Egypt

\begin{abstract}
The present study aims to investigate the age and growth parameters as well as food and feeding habits of Bagrus bayad (Forskal, 1775) and Bagrus docmac (Forskal, 1775), belonging to the family Bagridae in the Muess Channel of Sharkia Province, Egypt. The relationship between total fish length and vertebra radius is described by straight line equations: $L=6.714+13.88 \mathrm{~V}$ and $L=8.841+10.7 \mathrm{~V}$ for both studied species, respectively. The equations of the length-weight relationship for both studied species are expressed as:

\section{$\mathrm{W}=0.0057 \times \mathrm{L}^{3.1} \quad$ for Bagrus bayad \\ $\mathrm{W}=0.0068 \times \mathrm{L}^{3.05} \quad$ for Bagrus docmac}

The vertebrae were used to estimate the growth parameters of von Bertalanffy's equation. It is found that the $L_{\infty}=87 \mathrm{~cm}, \mathrm{~K}=0.1591 / \mathrm{y}$ and $\mathrm{t}_{\mathrm{o}}=-1.25$ years for $B$. bayad and $\mathrm{L} \infty=89 \mathrm{~cm}, \mathrm{~K}=0.1691 / \mathrm{y}$ and $\mathrm{t}_{\mathrm{o}}=-1.275$ years for $B$. docmac. Food and feeding habits of the two cat fish species were also studied through analysis of their stomach contents. B. docmac feeds mainly on invertebrates represented in shrimps, amphipoda, bivalvia and cephallopoda, while the most important food items of B.bayad are fish especially from Telapins and Clarias spp., together with parts of unidentified fishes.
\end{abstract}

Keywords: Bagrus bayad; Bagrus docmac; Feeding habits; Muess channel

\section{Introduction}

In Nile and its tributaries, the genus Bagrus of family Bagridae has two species, Bagrus bayad, and Bagrus docmac forming arealistic proportion of the commercial catches in Egyptian fresh waters [1]. The Bagrid fishes are commonly known as naked catfishes. They have four pair's of barbells enriched with well-developed taste bud [2]. One of the most famous morphological differences between B. bayad and B. docmac is that in the former; both lobes of the caudal fin are prolonged into long filaments whereas in the later; this is only so for the upper lobe [3].

Generally, Bagrus docmac is probably associated with rocky bottoms; coarse substrates [4] in both shallow and deep water [5]. Olaosebikan and Raji declared that, it is wide spread in lakes, swamps and rivers [6]. Bailey [7] Alhassan and Ansu-Darko [8] declared that Bagrus bayad is a benthic omnivorous feeder (bottom feeder) as they proved the presence of detritus (bottom deposit) in addition to the other food items inside the alimentary tract.

The food and feeding habit of Bagrus species were reported by several workers many years ago till now, among them Reed et al., Holden and Reed, Adebisi, Ipinjolu et al., Abdullahi and Abolude and Malami and Magawata may be mentioned [9-14]. Understanding the stomach contents of fish is very useful in guiding towards formulation of artificial diets in fish culture [15]. Fish exploit food substances in aquatic ecosystem according to their possessed adaptations (mouth, gill rakers, dentition and gut system) which are related to feeding. The focus of the present study is directed to through light on age and growth as well as the food habits of two fish species Bagrus bayad and Bagrus docmac. This may help in management of fisheries exploitation of the two species in Muess channel.

\section{Materials and Methods}

\section{Fish samples}

A total of 497 specimens of Bagrus bayad and 332 specimens of
Bagrus docmac in the present study were collected from October 2011 to September 2012 by fisher mens along Muess Channel, one of the Nile tributaries, of Sharkia Province, Egypt. As soon as the fish specimens were obtained, they transported in ice bag to the laboratory in Zoology Department, Faculty of science, Zagazig University. First of all, the total length to the nearest $\mathrm{mm}$. and total weight to the nearest gram of each fish was measured.

\section{Age determination}

The $3 \mathrm{ed}, 4^{\text {th }}$ and $5^{\text {th }}$ abdominal vertebrae of each fish were taken and boiled in water for about 25 minutes to remove all the suspended tissues. Vertebrae after then were washed and let to dry for later check under reflected light microscope with magnification of (X 20) with the aid of xylene as clearing agent. The age of each fish was determined by counting the complete ring of the centrum of the third vertebra of the fish.

\section{Time of annual ring formation}

In order study the time of ring formation to establish its annular nature, the vertebrae representing rings under formation (growth checks) at the outer margin in different months were examined. To clarify further, the time of annulus formation, the distance from the last annulus to the margin of the vertebrae were measured. A plot of monthly frequency of such vertebrae which have marginal rings indicated the seasonal and established the annual nature.

*Corresponding author: El-Drawany MA, Department of Zoology, Faculty of Science, Zagazig University, Egypt, E-mail: samy_drawany@yahoo.com

Received April 11, 2015; Accepted April 21, 2015; Published June 15, 2015

Citation: El-Drawany MA, Elnagar WG (2015) Growth, Food and Feeding Habits of Bagrus bayad and Bagrus docmac Inhibiting Muess Channel, Sharkia Province Egypt. J Aquac Res Development 6: 348. doi:10.4172/2155-9546.1000348

Copyright: $\odot 2015$ El-Drawany MA, et al. This is an open-access article distributed under the terms of the Creative Commons Attribution License, which permits unrestricted use, distribution, and reproduction in any medium, provided the original author and source are credited. 
Citation: El-Drawany MA, Elnagar WG (2015) Growth, Food and Feeding Habits of Bagrus bayad and Bagrus docmac Inhibiting Muess Channel, Sharkia Province, Egypt. J Aquac Res Development 6: 348. doi:10.4172/2155-9546.1000348

Page 2 of 8

\section{Total length-vertebral radius relationship}

The body length-vertebral radius relationship was determined using the least square method. The back calculated lengths at the end of each year of life were obtained by using Lee's equation [16]

$$
L=a+b V
$$

Where: $\mathrm{L}=$ total length of the fish

$\mathrm{V}=$ vertebral radius, $\mathrm{A}$ and $\mathrm{b}=$ regression factors.

Lengths of the fish at the end of each year of its life were estimated using the back calculation method of Lee [16]

$$
L_{n}=\left(V_{n} / \mathrm{V}\right)(\mathrm{L}-\mathrm{a})+\mathrm{a}
$$

Where $:\left(L_{n}\right)$ is the calculated length at the end of $(n)$ years, $(L)$ is the total length at capture, $\left(\mathrm{V}_{\mathrm{n}}\right)$ vertebral radius at annulus $(\mathrm{n}),(\mathrm{V})$ is the total vertebral radius and $(\mathrm{a})$ is intercept of $(\mathrm{Y})$ axis which indicates the length of fish before annulus formation. Growth was expressed in terms of the von Bertalanffy's equation [17]

$$
L_{t}=L_{\infty}\left(1-e^{-k(t-10)}\right)
$$

Where $(\mathrm{L} \infty)$ is the asymptotic total length, $\left(\mathrm{L}_{\mathrm{t}}\right)$ is the total length at age $(\mathrm{t}),(\mathrm{K})$ the growth curvature parameter and $\left(\mathrm{t}_{\mathrm{o}}\right)$ is the theoretical age when fish would been at zero total length. These parameters were estimated by means of the Ford and Walford plot $[18,19]$.

According to Hile, the length-weight relationship of fish species can be described by the following equation: [20]

$$
W=a L^{b}
$$

Where: $(\mathrm{W})$ is the total fish weight in grams, $(\mathrm{L})$ is the fish length in centimeters, (a) is a constant which varies from species to another, (b) is the regression coefficient.

\section{Food and feeding habits studies}

Analysis of stomach contents: Stomachs of all fish specimens were removed and tied at both ends then preserved in $10 \%$ formalin for later examination. Prey items were identified and counted under microscope and data were recorded. The number of empty stomachs as well as those containing food were determined for both species.

Analysis of data: Five indices were used to discuss the food and feeding habits:

1- Percentage numerical abundance $\left(C_{n}\right)=$ the number of each prey item in all the non-empty stomachs in proportion to the total number of all food items.

2- Percentage frequency of occurrence $(\% \mathrm{O})=$ the number of stomachs in which a food item was found in proportion to the number of all non-empty stomachs.

3- Index of relative importance (IRI), It is determined according to the formula;

$I R I=100\left(A I / \sum A I\right)$ Where: $\mathrm{AI}$ is the absolute importance index, obtained as follows:

$$
A I=\% O+\% C_{n}
$$

4-Vacuity index VI=(No. of empty stomachs/total No. of stomachs $) \times 100$

5-Fullness index $\mathrm{FI}=($ No. of non-empty stomachs/total No. of stomachs) $\times 100$

\section{Results}

From the present investigations, it was found that, the relationship between the total fish lengths and the vertebral radii of both fish species which are illustrated in Figures 1 and 2 are represented by the strait line equations:

For B. bayad is: $\mathrm{L}=6.714+13.88 \mathrm{~V} \mathrm{r}=0.9908$ and

For B. docmac is: $\mathrm{L}=8.841+10.7 \mathrm{~V} \quad \mathrm{r}=0.9321$

\section{The time of the annulus formation}

Means the time at which a complete annulus is formed at the margin of the vertebrae, this time is determined by using the marginal increment analysis or marginal growth which means the ratio between the distance from the last annulus to the margin and the total radius of the vertebrae.

Marginal growth is used in the determination of the time of

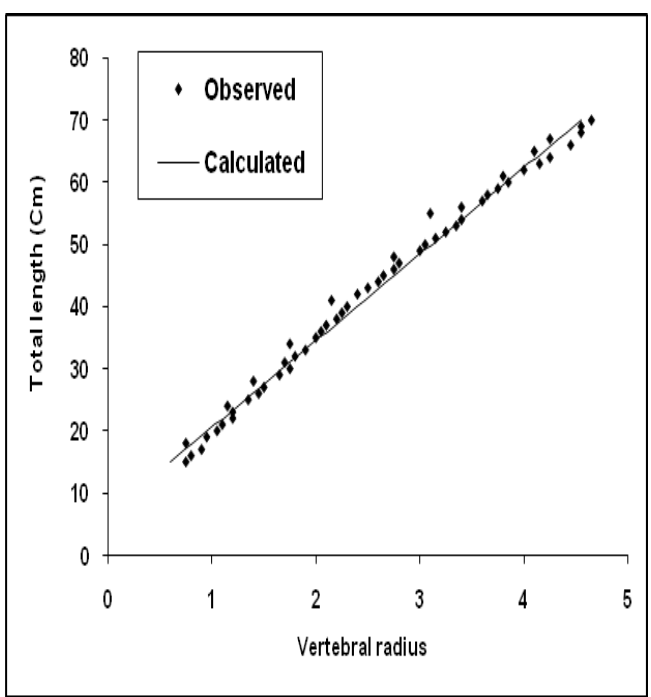

Figure 1: Total length -vertebral radius relationship of $B$. bayad.

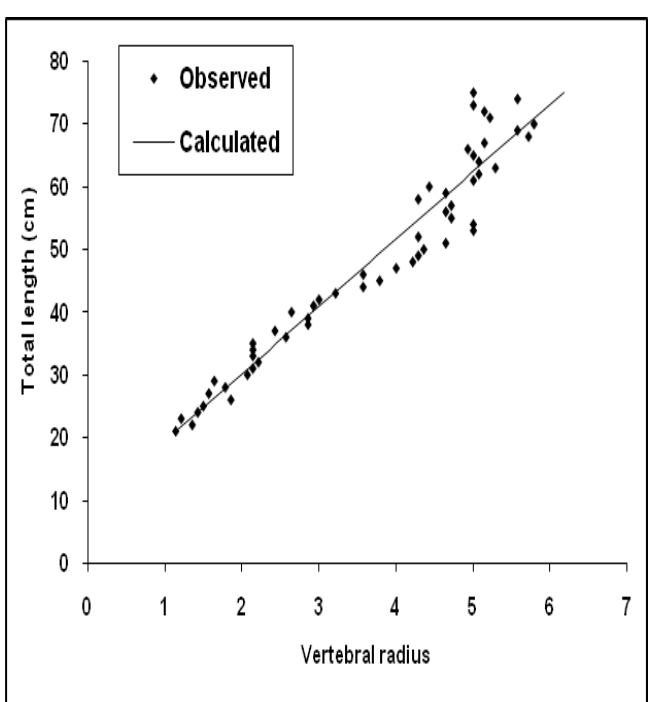

Figure 2: Total length-vertebral radius relationship of $B$. docmac. 
Citation: El-Drawany MA, Elnagar WG (2015) Growth, Food and Feeding Habits of Bagrus bayad and Bagrus docmac Inhibiting Muess Channel, Sharkia Province, Egypt. J Aquac Res Development 6: 348. doi:10.4172/2155-9546.1000348

Page 3 of 8

\begin{tabular}{|c|c|c|c|c|c|c|c|c|c|c|c|c|}
\hline Month & Jan. & Feb. & Mar. & Apr. & May & June & July & Aug. & Sept. & Oct. & Nov. & Dec. \\
\hline No. Of fishes & 5 & 7 & 10 & 11 & 8 & 15 & 7 & 10 & 8 & 12 & 9 & 4 \\
\hline $\begin{array}{l}\text { Marginal increment } \\
(\mathrm{mmX} \times \mathbf{4})\end{array}$ & 0.053 & 0.054 & 0.054 & 0.018 & 0.018 & 0.020 & 0.028 & 0.037 & 0.047 & 0.051 & 0.052 & 0.053 \\
\hline
\end{tabular}

Table 1: Monthly variations of marginal increment of the abdominal vertebrae of $B$. bayad of age (III).

\begin{tabular}{|c|c|c|c|c|c|c|c|c|c|c|c|c|}
\hline Month & Jan. & Feb. & Mar. & Apr. & May & June & July & Aug. & Sept. & Oct. & Nov. & Dec. \\
\hline No. Of fishes & 7 & 15 & 12 & 9 & 18 & 20 & 21 & 16 & 13 & 10 & 10 & 9 \\
\hline $\begin{array}{l}\text { Marginal increment } \\
(\mathrm{mmX} \times 40)\end{array}$ & 0.054 & 0.054 & 0.054 & 0.012 & 0.017 & 0.021 & 0.030 & 0.039 & 0.048 & 0.050 & 0.051 & 0.052 \\
\hline
\end{tabular}

Table 2: Monthly variations of marginal increment of the abdominal vertebrae of $B$. docmac of age (III).

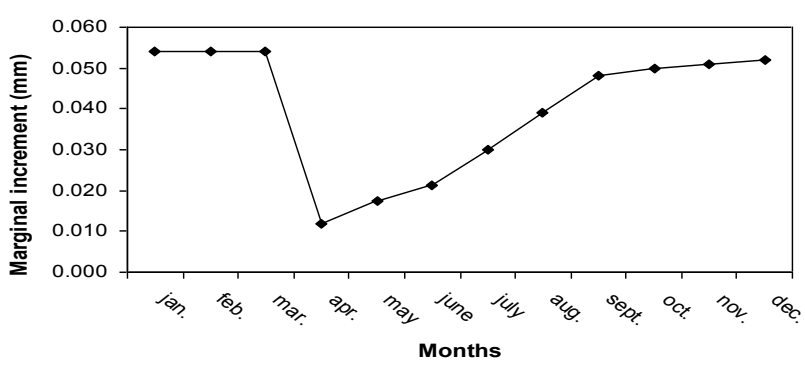

Figure 3: Monthly record of marginal Growth for the vertebrae of B. bayad.

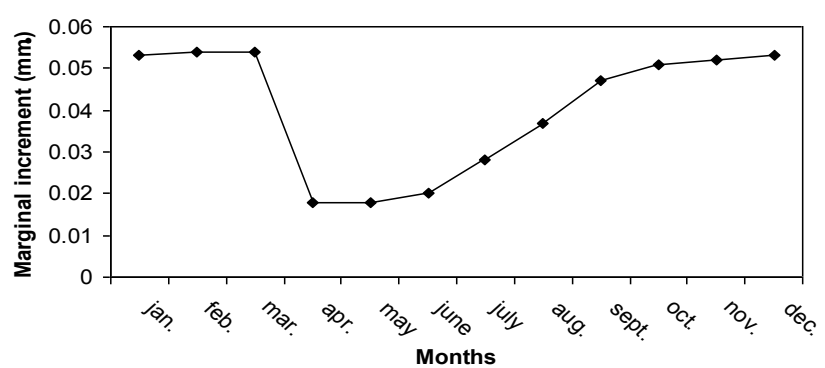

Figure 4: Monthly record of marginal Growth for the vertebrae of B.docmac.

annulus formation by comparing the value of marginal growth at each month of the year, the least value of marginal growth points out to the month at which the last annulus was formed. From Tables 1 and 2, Figures 3 and 4 , it is clear that the least values of marginal growth for both B. bayad and B. docmac were in April, which were 0.012 and 0.018 respectively, and this means that the annual rings were formed in the period of spring in both species.

\section{Growth in length}

The back calculation was made for 497 fish specimens of B. bayad at the end of each year of life ranging in lengths between $25-69 \mathrm{~cm}$, and for 332 fish specimens of $B$. docmac ranging between $28-75 \mathrm{~cm}$ Tables 3 and 4 . Back calculation of fish length at the progressive years of life computed by Lee's formula as:

$$
\begin{gathered}
L_{n}=(L-6.714)\left(V_{n} / V\right)+6.714 \text { For B. bayad and } \\
L_{n}=(L-8.841)\left(V_{n} / V\right)+8.841 \text { For B. docmac. }
\end{gathered}
$$

Accordingly, the growth parameters calculated on the basis of von Bertalanffy's growth equation are: $\mathrm{L}_{\infty}=$ were $87 \mathrm{~cm}, \mathrm{~K}=0.1591 / \mathrm{y}$ and $\mathrm{t}_{\mathrm{o}}=-1.25$ years for $B$. bayad and $\mathrm{L}_{\infty}=89 \mathrm{~cm}, \mathrm{~K}=0.1691 / \mathrm{y}$ and $\mathrm{t}_{\mathrm{o}}=-1.275$ years for $B$. docmac. The calculated and observed total lengths at age

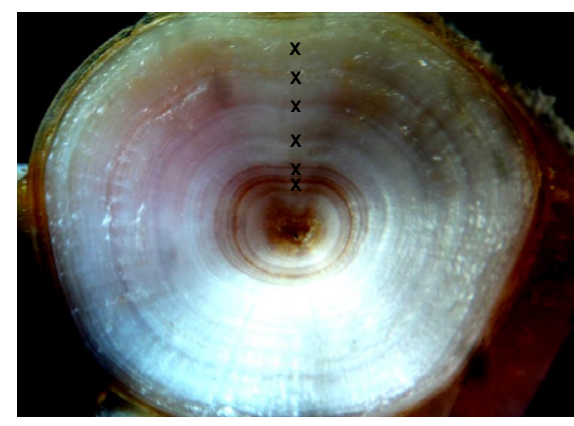

Figure 5: A 20X magnified centrum of third vertebra of Bagrus bayad with clear annual rings taken from a fish of $60 \mathrm{~cm}$ total length at age group VI.

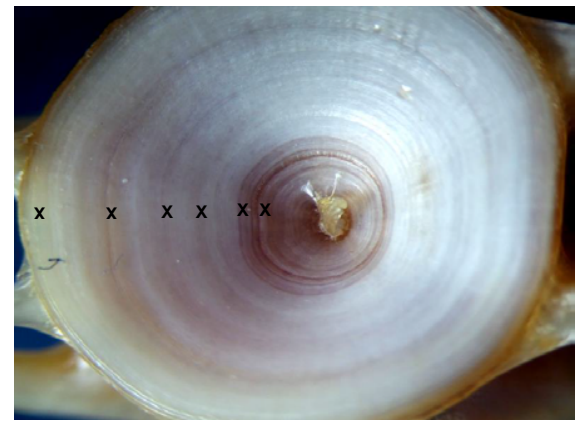

Figure 6: A 20X magnified centrum of third vertebra of Bagrus docmac with clear annual rings taken from a fish of $64 \mathrm{~cm}$ total length at age group V1.

data of both species are presented in Figures 5 and 6, Tables 5 and 6 .

\section{Length-weight relationship}

The equations of the length-weight relationship for both studied species are represent in Figures 7 and 8 and expressed by the following equations:

$$
\begin{aligned}
& W=0.0057 X L^{3.1} \text { for Bagrus bayad } \\
& W=0.0068 X L^{3.05} \text { for Bagrus docmac }
\end{aligned}
$$

From the equations it was found that, the weight of both species increase in proportion to about the cube of their body length (3.1 for $B$. bayad and 3.05 for B.docmac), which proves that both are of isometric growth.

\section{Food and feeding habits}

The index of relative importance (IRI) is most preferable to accurately indicate the degree of consumption of each food item. 
Citation: El-Drawany MA, Elnagar WG (2015) Growth, Food and Feeding Habits of Bagrus bayad and Bagrus docmac Inhibiting Muess Channel, Sharkia Province, Egypt. J Aquac Res Development 6: 348. doi:10.4172/2155-9546.1000348

Page 4 of 8

\begin{tabular}{|c|c|c|c|c|c|c|c|c|c|c|c|}
\hline $\begin{array}{c}\text { Average } \\
\text { T.L. }\end{array}$ & Age & No. & I & II & III & IV & $\mathbf{V}$ & VI & VII & VIII & IX \\
\hline 25 & I & 134 & 24.3 & & & & & & & & \\
\hline 36 & II & 38 & 23.9 & 34.8 & & & & & & & \\
\hline 42 & III & 84 & 24.8 & 34 & 43.1 & & & & & & \\
\hline 49 & IV & 99 & 26.1 & 35 & 42.7 & 51 & & & & & \\
\hline 55 & V & 56 & 24.9 & 34.6 & 42.1 & 49.7 & 55 & & & & \\
\hline 59 & VI & 33 & 24.5 & 34.5 & 40.9 & 49.9 & 54.1 & 58 & & & \\
\hline 64 & VII & 32 & 25.2 & 34.7 & 42.5 & 49.5 & 54.7 & 59.2 & 63.9 & & \\
\hline 67 & VIII & 20 & 25.5 & 34.1 & 42 & 49.2 & 54.3 & 58.7 & 62.9 & 67.1 & \\
\hline 69 & IX & 1 & 24.9 & 36 & 41.4 & 50.9 & 53.4 & 58.7 & 64.5 & 66.8 & 70.2 \\
\hline \multicolumn{3}{|c|}{ average } & 24.9 & 34.7 & 42.1 & 50 & 54.3 & 58.7 & 63.8 & 67 & 70.2 \\
\hline \multicolumn{3}{|c|}{ increment } & 24.9 & 9.8 & 7.4 & 7.9 & 4.3 & 4.4 & 5.1 & 3.2 & 3.2 \\
\hline \multicolumn{3}{|c|}{$\%$ increment } & 35.5 & 14.0 & 10.5 & 11.3 & 6.1 & 6.3 & 7.2 & 4.5 & 4.6 \\
\hline
\end{tabular}

Table 3: The average back calculated lengths in different years of life for B.bayad.

\begin{tabular}{|c|c|c|c|c|c|c|c|c|c|c|c|c|}
\hline $\begin{array}{c}\text { Average } \\
\text { T.L. }\end{array}$ & Age & No. & I & II & III & IV & $\mathbf{V}$ & VI & VII & VIII & IX & $x$ \\
\hline 28 & I & 52 & 29 & & & & & & & & & \\
\hline 37 & II & 76 & 27.6 & 39.1 & & & & & & & & \\
\hline 45 & III & 45 & 28 & 36.2 & 45.2 & & & & & & & \\
\hline 53 & IV & 47 & 26.5 & 38 & 46.5 & 50.9 & & & & & & \\
\hline 58 & $\mathbf{v}$ & 29 & 27.1 & 36.5 & 45 & 52.9 & 60.9 & & & & & \\
\hline 62 & VI & 39 & 25.8 & 37.1 & 46.5 & 51.3 & 58.9 & 64.1 & & & & \\
\hline 67 & VII & 12 & 27.5 & 35.5 & 44.8 & 54.8 & 56.6 & 60.9 & 65.3 & & & \\
\hline 70 & VIII & 23 & 28.1 & 37.5 & 45.5 & 52.7 & 57.6 & 62.5 & 67 & 70.6 & & \\
\hline 73 & IX & 8 & 28.4 & 38.1 & 47.5 & 53.5 & 55.5 & 61.8 & 68.2 & 69.9 & 73.4 & \\
\hline 75 & $x$ & 1 & 27 & 37 & 47.4 & 51.8 & 56.1 & 62.9 & 66.8 & 71.5 & 74 & 76.4 \\
\hline \multicolumn{3}{|c|}{ average } & 27.5 & 37.2 & 46.1 & 52.6 & 57.6 & 62.4 & 66.8 & 70.7 & 73.7 & 76.4 \\
\hline \multicolumn{3}{|c|}{ increment } & 27.5 & 9.7 & 8.9 & 6.5 & 5.0 & 4.8 & 4.4 & 3.9 & 3.0 & 2.7 \\
\hline \multicolumn{3}{|c|}{$\%$ increment } & 36.0 & 12.7 & 11.6 & 8.5 & 6.6 & 6.3 & 5.7 & 5.0 & 4.0 & 3.5 \\
\hline
\end{tabular}

Table 4: The average back calculated lengths in different years of life for $B$. docmac.

\begin{tabular}{|c|c|c|c|c|c|c|c|}
\hline \multirow{2}{*}{$\begin{array}{l}\text { Age in } \\
\text { years }\end{array}$} & \multirow[b]{2}{*}{ No. } & \multicolumn{4}{|c|}{ Length in $(\mathrm{cm})$} & \multicolumn{2}{|c|}{ Weight in (g) } \\
\hline & & Length group & $\begin{array}{l}\text { Observed average } \\
\text { length }\end{array}$ & $\begin{array}{l}\text { From back } \\
\text { calculation }\end{array}$ & $\begin{array}{l}\text { Calculated from Von } \\
\text { Bertlanffy's }\end{array}$ & $\begin{array}{c}\text { Calculated from } \\
\text { increments summation }\end{array}$ & $\begin{array}{c}\text { Calculated from Von } \\
\text { Bertlanffy's }\end{array}$ \\
\hline 1 & 134 & $15-35$ & 26 & 24.9 & 26.1 & 155.75 & 140.6 \\
\hline II & 38 & $32-40$ & 35 & 34.7 & 35 & 447.68 & 349.8 \\
\hline III & 84 & $37-47$ & 43 & 42.1 & 42.7 & 814.20 & 643.7 \\
\hline IV & 99 & $46-54$ & 50 & 50 & 49.2 & 1390.05 & 999.2 \\
\hline $\mathbf{V}$ & 56 & $53-59$ & 55 & 54.3 & 54.7 & 1790.95 & 1392 \\
\hline VI & 33 & $57-61$ & 60 & 58.7 & 59.4 & 2279.92 & 1800.5 \\
\hline VII & 32 & $60-66$ & 64 & 63.8 & 63.5 & 2947.49 & 2207.7 \\
\hline VIII & 20 & $64-70$ & 67 & 67 & 66.9 & 3426.85 & 2601.1 \\
\hline IX & 1 & $\geq 70$ & 70 & 70.2 & 69.9 & 3969.23 & 2972.4 \\
\hline
\end{tabular}

Table 5: Ranges and means of empirical lengths and weights for B. bayad.

From the Table 7 and Figure 9 it is found that, the most important food items of B. bayad are fishe specially from Telapins and Clarias $s p p$., together with parts of unidentified fishes. Telapians have an IRI greater than all food items (14.87) followed by unidentified fish remains having (18.96) whereas Clarias spcs. represents (8.33). B. bayad, selects only coleoptra (insecta) with an IRI of 10.58 butfrom invertebrates shrimps and nematode warms have relatively high IRI (7.96 and 7.01 respectively), then amphipoda, bivalvia and gastropoda with IRI values of 6.03, 3.7 and 4.2 respectively. Vegetable materials represented 12.75 IRI.

B. docmac feeds mainly on invertebrates represented in shrimps, amphipoda, bivalvia and cephallopoda arranged descendingly in IRI value 11.9, 9.6, 7.2 and 6.82, respectively (Table 7 and Figure 10). Fishes side by side with insects have approximately the same importance with values 25.0 and 24.2 respectively; among fishes, only telapians were found together with remains of unidentified fish with about 15.3 and 9.75 IRI values respectively. Insects were represented in coleoptera, diptera and odonata with IRI values $10.53,8.33$ and 5.37 respectively. Vegetable materials recorded an IRI value of 9.94 (Table 7 and Figure 10).

\section{Seasonal variations in the consumption of each food item}

Bagrus bayad: From Table 8 Nematode warms, appear in the stomach of investigated $B$. bayad in winter with low value 7.82 of IRI which increased slightly in spring and summer to about 8.5 but they disappeared completely in autumn. No insects were found in the stomachs in winter, while it appeared in all other seasons with highest 
Citation: El-Drawany MA, Elnagar WG (2015) Growth, Food and Feeding Habits of Bagrus bayad and Bagrus docmac Inhibiting Muess Channel, Sharkia Province, Egypt. J Aquac Res Development 6: 348. doi:10.4172/2155-9546.1000348

Page 5 of 8

\begin{tabular}{|c|c|c|c|c|c|c|c|}
\hline \multirow{2}{*}{$\begin{array}{l}\text { Age in } \\
\text { years }\end{array}$} & \multirow[b]{2}{*}{ No. } & \multicolumn{4}{|c|}{ Length in $(\mathrm{cm})$} & \multicolumn{2}{|c|}{ Weight in (g) } \\
\hline & & Length group & $\begin{array}{l}\text { Observed average } \\
\text { length }\end{array}$ & $\begin{array}{l}\text { From back } \\
\text { calculation }\end{array}$ & $\begin{array}{c}\text { Calculated from Von } \\
\text { Bertlanffy's }\end{array}$ & $\begin{array}{l}\text { Calculated from } \\
\text { increments summation }\end{array}$ & $\begin{array}{c}\text { Calculated from Von } \\
\text { Bertlanffy's }\end{array}$ \\
\hline I & 52 & $21-35$ & 29 & 27.5 & 28.4 & 167.46 & 184.3 \\
\hline II & 76 & $30-44$ & 38 & 37.2 & 37.8 & 421.21 & 441.5 \\
\hline III & 45 & $40-50$ & 46 & 46.1 & 45.8 & 805.38 & 790.2 \\
\hline IV & 47 & $48-58$ & 53 & 52.6 & 52.5 & 1205.61 & 1199.9 \\
\hline $\mathbf{V}$ & 29 & $55-61$ & 59 & 57.6 & 58.2 & 1596.56 & 1640.9 \\
\hline VI & 39 & $58-66$ & 63 & 62.4 & 63 & 2037.38 & 2088.9 \\
\hline VII & 12 & $65-69$ & 67 & 66.8 & 67 & 2505.50 & 2525.9 \\
\hline VIII & 23 & $68-72$ & 71 & 70.7 & 70.4 & 2969.82 & 2939.7 \\
\hline IX & 8 & $72-74$ & 74 & 73.7 & 73.3 & 3375.26 & 3322.8 \\
\hline $\mathbf{x}$ & 1 & $\geq 75$ & 75 & 76.4 & 75.8 & 3766.55 & 3671.3 \\
\hline
\end{tabular}

Table 6: Ranges and means of empirical lengths and weights for $B$. docmac.

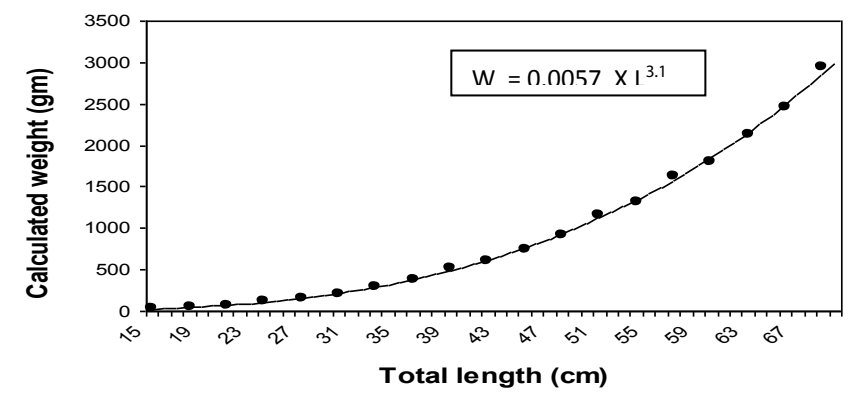

Figure 7: Length-weight relationship of B. bayad.

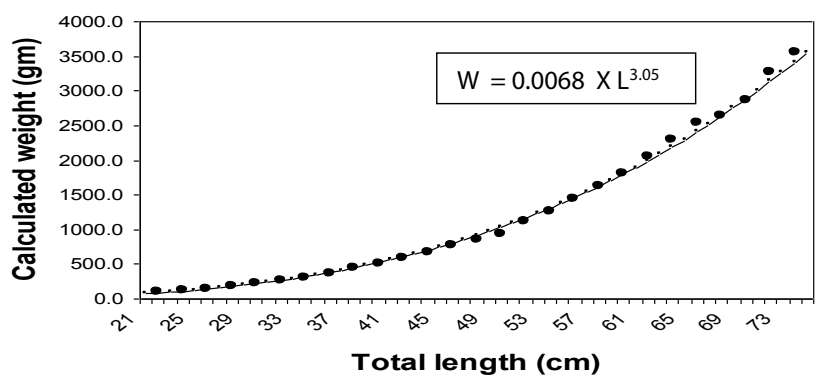

Figure 8: Length-weight relationship of $B$. docmac.

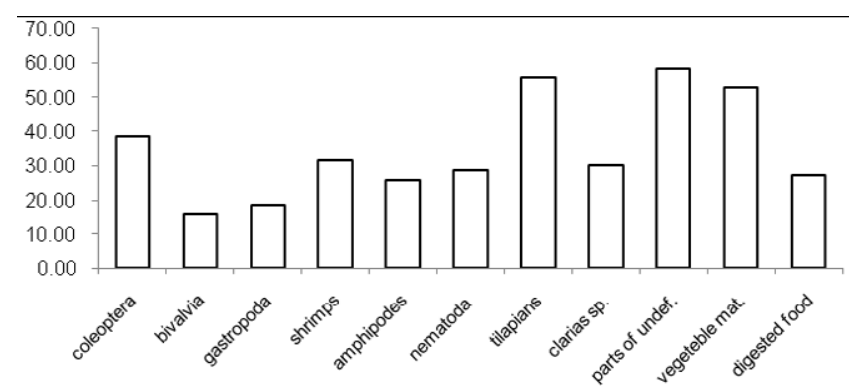

Figure 9: Frequency of occurrence of Major food items in the diet of $B$. bayad.

value in summer about 12.5. Investigated Bagrus bayad showed low appetite for eating molluscka all over the year as it had the lowest values of IRI between all food items until it completely disappeared in summer.

\begin{tabular}{|c|c|c|c|c|c|c|}
\hline \multirow{2}{*}{ Food item } & \multicolumn{2}{|l|}{$\left(C_{n}\right)$} & \multicolumn{2}{|l|}{ (0) } & \multicolumn{2}{|l|}{ (IRI) } \\
\hline & bayad & docmac & bayad & docmac & bayad & docmac \\
\hline Insects & 12.5 & 21.4 & 38.57 & 51.72 & 10.58 & 24.23 \\
\hline Diptera & ------------ & 7.3 & |----------- & 36.21 & |----------- & 8.33 \\
\hline Coleoptera & 12.5 & 10.2 & 38.57 & 44.83 & 10.58 & 10.53 \\
\hline Odonata & ----------- & 3.9 & |---------- & 24.14 & ----------- & 5.37 \\
\hline Invertebrates & 19.5 & 33.7 & 45.71 & 62.07 & 28.89 & 35.49 \\
\hline Mollusks & 3.8 & 11.8 & 24.29 & 25.86 & 7.89 & 7.21 \\
\hline Bivalvia & 2.3 & 11.8 & 15.71 & 25.86 & 3.73 & 7.21 \\
\hline Gastropoda & 1.5 & |----------- & 18.57 & |----------- & 4.16 & --.- \\
\hline Crustaceans & 10.4 & 15.6 & 35.71 & 62.07 & 13.99 & 21.47 \\
\hline Shrimps & 7 & 10.5 & 31.43 & 51.72 & 7.96 & 11.91 \\
\hline Amphipods & 3.4 & 5.1 & 25.71 & 44.83 & 6.03 & 9.56 \\
\hline Other invertebrate & 5.3 & 6.3 & 28.57 & 29.31 & 7.01 & 6.82 \\
\hline Nematodes & 5.3 & |----------- & 28.57 & |----------- & 7.01 & ---- \\
\hline Cephalopods & ------------ & 6.3 & |----------- & 29.31 & |----------- & 6.82 \\
\hline Fishes & 59.3 & 39.5 & 67.14 & 70.69 & 42.16 & 25.05 \\
\hline Tilapians & 16.1 & 26.5 & 55.71 & 53.45 & 14.87 & 15.30 \\
\hline Clarias sp. & 10.2 & |------------ & 30.00 & |------------ & 8.33 & |-- \\
\hline Parts of fishes & 33 & 13 & 58.57 & 37.93 & 18.96 & 9.75 \\
\hline Vegetable mat. & 8.7 & 5.4 & 52.86 & 46.55 & 12.75 & 9.94 \\
\hline Digested food & |----------- & |------------ & 27.14 & 27.59 & 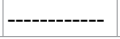 & - \\
\hline
\end{tabular}

Table 7: Major food items of $B$. bayad and $B$. docmac presents in numerical abundance $\left(C_{n}\right)$, frequency of occurrence $(O)$ and index of relative importance (IRI)

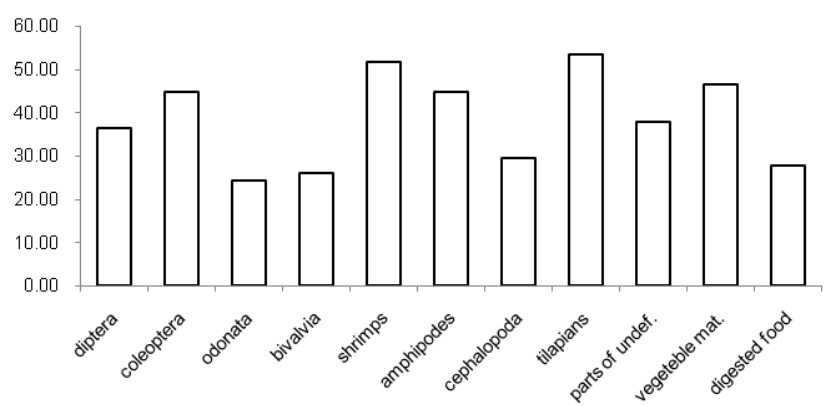

Figure 10: Frequency of occurrence of major food items in the diet of $B$. docmac.

Only specimes of spring contained all food items, the greatest consumption was for the parts of unidentified fishes that has the highest IRI value of 19.09 and it increased in the rest of the year to between 21.5 and 23. Tilapia spp. comes with the greatest value in winter about (18) but Clarias spp. has relatively low values of IRI compared with Tilapia spp. ranging between 8.66 in spring and 10.53 in autumn. Crustacea with its two types (Shrimps and Amphipoda) is available for B. bayad 
Citation: El-Drawany MA, Elnagar WG (2015) Growth, Food and Feeding Habits of Bagrus bayad and Bagrus docmac Inhibiting Muess Channel, Sharkia Province, Egypt. J Aquac Res Development 6: 348. doi:10.4172/2155-9546.1000348

Page 6 of 8

\begin{tabular}{|c|c|c|c|c|c|c|c|c|c|c|c|c|}
\hline \multirow{2}{*}{ Food items } & \multicolumn{3}{|c|}{ autumn } & \multicolumn{3}{|c|}{ winter } & \multicolumn{3}{|c|}{ spring } & \multicolumn{3}{|c|}{ summer } \\
\hline & $\% C_{n}$ & $\%$ O & \%IRI & $\% C_{n}$ & $\%$ O & \%IRI & $\% C_{n}$ & $\%$ O & \%IRI & $\% C_{n}$ & $\%$ O & \%IRI \\
\hline Coleoptera & 9.6 & 37.14 & 10.91 & $* * *$ & $* * *$ & $* * *$ & 12.4 & 40 & 11.46 & 15.8 & 38.57 & 12.52 \\
\hline Bivalvia & 3.5 & 15.71 & 4.48 & 5.3 & 18.57 & 5.55 & 2.3 & 14.29 & 3.63 & 2.1 & 14.29 & 3.77 \\
\hline Gastropoda & 3.2 & 15.71 & 4.41 & 4.5 & 20.00 & 5.70 & 1 & 21.43 & 4.91 & $* * *$ & $* * *$ & $* * *$ \\
\hline Shrimp & 10.4 & 31.43 & 9.76 & 7.9 & 30.00 & 8.81 & 7 & 32.86 & 8.72 & 6.3 & 28.57 & 8.03 \\
\hline Amphipoda & 4.9 & 22.86 & 6.48 & 3.5 & 25.71 & 6.79 & 3.8 & 24.29 & 6.14 & 2.3 & 25.71 & 6.45 \\
\hline nematodes & $* * *$ & $* \star *$ & $\star \star \star *$ & 6.5 & 27.14 & 7.82 & 8 & 32.86 & 8.94 & 5.3 & 31.43 & 8.46 \\
\hline tilapians & 14.3 & 55.71 & 16.34 & 16.6 & 60.00 & 17.81 & 14.9 & 57.14 & 15.76 & 15.2 & 52.86 & 15.67 \\
\hline Clarias sp. & 9.4 & 35.71 & 10.53 & 9.3 & 32.86 & 9.80 & 9.6 & 30.00 & 8.66 & 10.1 & 28.57 & 8.90 \\
\hline parts of fishes & 36 & 61.43 & 22.73 & 35 & 57.14 & 21.43 & 33 & 54.29 & 19.09 & 34 & 58.57 & 21.32 \\
\hline Vegetable mat. & 8.7 & 52.86 & 14.36 & 11.4 & 58.57 & 16.27 & 8 & 50.00 & 12.69 & 8.9 & 55.71 & 14.88 \\
\hline Digested food & $* \star *$ & 28.57 & $* * *$ & $* * *$ & 27.14 & $* * *$ & $* * *$ & 27.14 & $* \star *$ & $* * *$ & 25.71 & $* * *$ \\
\hline
\end{tabular}

Table 8: Seasonal variations in the consumption of food by B. bayad.

\begin{tabular}{|c|c|c|c|c|c|c|c|c|c|c|c|c|}
\hline \multirow{2}{*}{ Food item } & \multicolumn{3}{|c|}{ autumn } & \multicolumn{3}{|c|}{ winter } & \multicolumn{3}{|c|}{ spring } & \multicolumn{3}{|c|}{ summer } \\
\hline & $\% \mathrm{Cn}$ & $\% \mathrm{O}$ & \%IRI & $\% \mathrm{Cn}$ & $\% \mathrm{O}$ & \%IRI & $\% \mathrm{Cn}$ & $\% O$ & \%IRI & $\% \mathrm{Cn}$ & $\% \mathrm{O}$ & \%IRI \\
\hline Diptera & 8 & 36.21 & 9.68 & 7.7 & 37.93 & 9.62 & 9.8 & 34.48 & 9.80 & 8 & 36.21 & 9.50 \\
\hline Coleoptera & 10.6 & 48.28 & 12.89 & 10.2 & 44.83 & 11.61 & 10 & 46.55 & 12.52 & 11.8 & 43.10 & 11.79 \\
\hline Odonata & 4 & 25.86 & 6.54 & $* * *$ & $* \star *$ & $* * *$ & 6.2 & 22.41 & 6.33 & 4.1 & 24.14 & 6.07 \\
\hline Bivalvia & 12.1 & 25.86 & 8.31 & 11.9 & 24.14 & 7.60 & 12 & 27.59 & 8.76 & 12 & 29.31 & 8.87 \\
\hline Shrimps & 12 & 48.28 & 13.19 & 10.6 & 53.45 & 13.51 & 10.8 & 51.72 & 13.84 & 11 & 55.17 & 14.21 \\
\hline Amphipoda & $* * *$ & $* * *$ & $* * *$ & 5.5 & 43.10 & 10.25 & 4.7 & 44.83 & 10.96 & 4.6 & 46.55 & 10.99 \\
\hline Cephalopods & 7.2 & 29.31 & 7.99 & 6.5 & 27.59 & 7.19 & 6 & 31.03 & 8.20 & $* * *$ & $* * *$ & $* * *$ \\
\hline Tilapians & 26.8 & 56.90 & 18.32 & 27 & 51.72 & 16.60 & 26.5 & 53.45 & 17.70 & 27.1 & 50.00 & 16.56 \\
\hline parts of fishes & 13.2 & 41.38 & 11.95 & 13.8 & 41.38 & 11.64 & 14 & 39.66 & 11.88 & 16.3 & 34.48 & 10.91 \\
\hline Vegetable mat. & 6.1 & 44.83 & 11.15 & 6.8 & 50.00 & 11.98 & $* * *$ & $* * *$ & $* * *$ & 5.1 & 46.55 & 11.10 \\
\hline Digested food & $* * *$ & 27.59 & $* * *$ & $* \star *$ & 24.14 & $* \star *$ & $* * *$ & 25.86 & $* * *$ & $* * *$ & 29.31 & $* * *$ \\
\hline
\end{tabular}

Table 9: Seasonal variations in the consumption of food by $B$. docmac:

at the four seasons with higher consumption for shrimps (9.76) in autumnand (8.03) in summer. Plants are eaten by about half of fishes all over the year but, with relatively small amounts so it has a median value of IRI 16.27 recorded in winter.

Bagrus docmac: From Table 9 it is found that the highest consumption of B.docmac among all food items was Tilapia spp. in autumn as it records an IRI value 18.32, then it decreases to values between 16.56 and 17.7 at the rest of the year. The least degree of consumption was for odonata in summer with 6.07 IRI. B. docmac showed low appetite for eating this insect all over the year till it completely disappeared from its diet in winter in which the consumption of both diptera and coleopteran reached to 9.62 and 11.61, respectively from relatively higher values in spring and autumn for both types. Vegetarian consumption has been stopped in spring although vegetable material recorded relatively high IRI values; that approached 12.0 in winter. Shrimps recorded very high IRI values next to tilapians all over the year reaching 14.21 in summer, while amphipodes, has lesser values about 10.99 in summer then it disappeared completely in autumn. Bivalvia recorded its highest value of IRI 8.87 in summer and the least one 7.6 in winter (Table 9).

\section{Discussion}

In the present study, the relationship between the total length of both Bagrus spp. and the radius of vertebral centrum is represented by a straight line, indicating a linear relationship fitted by the least squares method. I.e. the relation between length and vertebral radius is very close which indicates that the vertebrae of Bagrus bayad and Bagrus docmac are optimum for the age determination. Results of the present work showed that the annuli appear on the vertebrae of both B. bayad and B. docmac in April. According to El-Sedfy they are formed in April.
This is in accordance with the present findings [21].

Many investigators gave extensive reviews on the factors affecting the time of formation of the annual rings. Le Cren mentioned that temperature has the greatest effect on the first and second year growth of Perca fluvialis [22]. Nikolsky showed that the formation of the annual rings is the result of an adaptive reconstruction of the course of metabolism within the fish body [23]. Bishai pointed out that temperature and food together with some internal and external factors interact causing the formation of the annual growth in sub-tropical fish as B. bayad whose annual rings formed in March [24].

The growth occurs as a result of addition of material to the body. Food supply and other environmental factors play an important role in determining the characteristics of growth, hence when the environmental conditions and the physiological status remain unchanged, the growth rate decreases with the age [25]. In the present study the most rapid growth of the both studied fish species occurs in the first year of life, after which the growth rate slowly decreases. Thus, the highest increment in length was attained between the first and second years.

The maximum age, length and weight for B. bayad and B. docmac recorded are IX and X years, 87 and $89 \mathrm{~cm}, 5867$ and $5999 \mathrm{~g}$ as respectively (Table 10).

The present observations revealed that although there is in no great significant difference in the growth of both Bagrus species, but it is clear that $B$. docmac grows faster and lives for a longer age than $B$. bayad. Hashem stated that $B$. bayad shows a slow rate of growth. But El-Badawy and Mohamed recorded a higher growth rate of $B$. docmac than that of B. bayad in their studies for both species [26-28]. 
Citation: El-Drawany MA, Elnagar WG (2015) Growth, Food and Feeding Habits of Bagrus bayad and Bagrus docmac Inhibiting Muess Channel, Sharkia Province, Egypt. J Aquac Res Development 6: 348. doi:10.4172/2155-9546.1000348

Page 7 of 8

\begin{tabular}{|c|c|c|c|c|c|c|}
\hline \multirow[t]{2}{*}{ Authors } & \multicolumn{2}{|c|}{ maximum length } & \multicolumn{2}{|c|}{ maximum weight } & \multicolumn{2}{|c|}{ maximum age } \\
\hline & B. bayad & B.docmac & B. bayad & B.docmac & B. bayad & B.docmac \\
\hline El-Sedfy (1976) & $\begin{array}{c}63.14 \text { male } \\
78.02 \text { female }\end{array}$ & 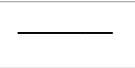 & $\longrightarrow$ & $\longrightarrow$ & VI & - \\
\hline Hashem 1977 & $\begin{array}{l}75 \text { male } \\
85 \text { female }\end{array}$ & 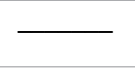 & $\begin{array}{c}3668 \text { males } \\
5057 \text { females }\end{array}$ & $\longrightarrow$ & VII & \\
\hline El-Badawy 1991 & & & 2789 & 11430 & V & VI \\
\hline Mohamed (2005) & 64.6 & 63.5 & 1788 & 2166 & VII & VII \\
\hline Kantoussan et al. (2009) & 75.6 & 86.6 & 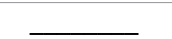 & & 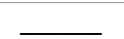 & 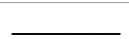 \\
\hline Present study (2014) & 87 & 89 & 5867 & 5999 & IX & $x$ \\
\hline
\end{tabular}

Table 10: Showing other results recorded by different authors.

The length-weight relationship of both Bagrus species is expressed as:

$W=-2.2443 \times L^{3.1}$ with $\mathrm{r}=0.9028$ for Bagrus bayad and

$W=-2.1675 \times L^{3.05}$ with $\mathrm{r}=0.9249$ for Bagrus docmac

which indicates their isometric growth ( $\mathrm{b}=3.1$ for Bagrus bayad and $\mathrm{b}=3.05$ for Bagrus docmac). These results are similar to those reported by Goudswaard and Witte for B. docmac in Lake Victoria (b=3.07). However, Ogbe et al. reported positive allometric growth pattern for Bagrus bayad from Lower Benue River [29,30]. While El-Badawy showed negative allometric growth for both Bagrus bayad $(b=2.8802)$ and Bagrus docmac $(\mathrm{b}=2.7858)$. Such variation in the type of growth may be ascribed on environmental changes and difference in the time of study.

In the present study it was found that B. bayad and B. docmac shared some food items like; Coleoptera from insects and bivalvia as well as shrimps amphipods from crustaceans and tilapia from fishes, this in addition to other food items specific for each of them. Many workers like as Imevbore and Bakare, Fagade and Olaniyan, Chilvers and Gee declared that, $B$. docmac is predominantly piscivorous. Nonetheless, others observed that it is polyphagic, feeds on fish and invertebrates or sometimes invertebrates only Sandon and Tayib, Petr, and Whyte [31-35]. Latif reported that B. bajad and B. docmac are carnivorous, feed mainly on fishes (Tilapia, Alestes, Synodontis, Mormyrus, Labeo, Barbus, Eutropius spp.), insect larvae, molluscs and freshwater shrimps. The percentage of each food item varies with different fish lengths [36].

The present work revealed also the presence of detritus in the stomach of B. bayad this agreed with the findings of Bailey and Alhassan and Ansu-Darko proved the presence of detritus in addition to the other food items such as zooplankton, fishes, insects, phytoplankton as well as insect parts [1,7].

Khallaf and Authman reported that, the presence of mud or sand and various odd materials in some of the stomachs examined of $B$. bayad suggests bottom feeding, whereas $B$. docmac depends mainly on fish and insects as food [8].

The monthly variation of stomach fullness index indicated a variation in feeding activity of $B$. bayad and $B$. docmac. Seasonally winter was characterized by lower values of FI than those of summer and spring for both species. This might be due to low availability of various food items in winter caused by a drop in temperature and shorter duration of daylight; this is in line with the observation of Khallaf and Authman [1]. In the size classes of 10 to $30 \mathrm{~cm}$ standard length, B. bayad and B. docmac show diet overlap and interact with each other especially with respect to tilapias as prey. After this length, $B$. docmac, aided by its relatively larger mouth, shifted to larger size of tilapias to coexist with B. bayad Khallaf and Authman [1].

\section{Conclusion}

This study aims to provide information on the length-weight relationship of this valuable fish species which will help in its management in the Muess Channel of Sharkia Province, Egypt. As well as the Stomach content analysis showed the food requirements of Bagrus bayad in the natural habitats which may serve as a measure for satisfying the species under culture condition. In view of the importance of stomach content analysis, studies should be extended to other native fish species so as to provide the scientific information for their management.

\section{Acknowledgement}

This research is part of the $\mathrm{PhD}$ thesis submitted to Faculty of Science University of Zagazig. The writers wish to express their deep gratitude to Dr. A. E. El-Agamy, professor of Fish biology, Faculty of science, Zagazig University for his valuable suggestions and for his reviewing the manuscript.

\section{References}

1. Khallaf EA, Authman MN (1992) Changes in diet, prey size and feeding habit in Bagrus bayad, and possible interactions with Bagrus docmac in a Nile canal. Environ Biol Fish 34: 425-431.

2. Zhang G, Deng S, Zhang H, Li H, Leilei L (2006) Distribution of different taste buds and expression of a-gustducin in the barbells of yellow catfish (Pelteobagrusfulvidraco). Fish Physiol Biochem 32: 55-62.

3. Sandon $H$ (1950) An illustrated guide to the freshwater fishes of the Sudan.

4. Lock JM (1982) The biology of siluriform fishes in Lake Turkana.

5. Witte F, De Winter W (1995) Fish stocks and fisheries of Lake Victoria. A handbook for field observations. Samara publishing limited, Great Britain.

6. Olaosebikan BO, Raji A (1998) Field guide to Nigerian freshwater fishes. Federal College of Freshwater Fisheries Technology, New Bussa, Nigeria.

7. Bailey MM (1994) Age, growth, maturity and sex comosition of the American smelt (Osmerusmordax, Mithel) of Western Lake Superior. Trans Amer Fish Soc 93: 382

8. Alhassan EH, Ansu-Darko M (2011) Food and Feeding Habits of a Potential Aquaculture Candidate, the Black Nile Catfish, Bagrus Bajadin the Golinga Reservoir. Australian Journal of Basic and Applied Sciences 5: 354-359.

9. Reed WJ, Buchard A, Hopson J, Jenness J, Yaro I (1967) Fish and fisheries of Northern Nigeria. Ministry of Agriculture, Northern Nigeria.

10. Holden M, Reed W (1972) West African fresh water fish. Longman publishers.

11. Adebisi AA (1980) Analyses of the stomach content of the piscivorous fishes of the upper Ogun River in Nigeria. Hydrobiologia 79: 167-177.

12. Ipinjolu JK, Garba SD, Bako GG (1988) Length-Weight relationship, Condition factor and stomach of B. bayad (Macropterus) in River Rima. Journal of Agriculture and Environment 2: 113-120.

13. Abdullahi SA, Abolude DS (2001) Some studies on the biology of Bagrus bayad (Daget) in Tiga Dam, Kano state Nigeria. Journal of Arid-zone fisheries 1: 1-11.

14. Malami GZ, Magawata I (2010) Analysis of Food And Feeding Habits of Catfish (Bagrus bayad, Macropterus (Daget) inRiver Rima and Goronyo Dam, in Sokoto State, Nigeria. Nigerian Journal of basic and Applied Science 18: 277-284. 
Citation: El-Drawany MA, Elnagar WG (2015) Growth, Food and Feeding Habits of Bagrus bayad and Bagrus docmac Inhibiting Muess Channel, Sharkia Province, Egypt. J Aquac Res Development 6: 348. doi:10.4172/2155-9546.1000348

Page 8 of 8

15. Fagade SO (1978) On the biology of Tilapia guineensis (Dumeril) from Lekki Lagoon. Lagos state, Nigeria. Nigerian Journal of Sciences 12: 73-85.

16. Lee RM (1920) A review of the methods of age and growth determination in fishes by means of scales.

17. Von Bertlanffy L (1949) Problems of organic growth. Nature 163: 156-158.

18. Ford $E$ (1933) An account of the herring investigation conducted at Plymouth during the years from 1924-1933. J Mar Bio Ass 19: 305-384.

19. Walford LA (1946) A new graphic method of describing the growth of animals Biol Bull 90: 141-147.

20. Hile R (1936) Age and growth of the cisco Leucichthysartedi (Le Sueur), in the Lakes of the North-Eastern highlands, Wisconsin. Bull U.S Bur Fish 48: 211-317

21. El-Sedfy HM (1976) Biological studies on Bagrus bayad in the Nile.

22. Le Cren ED (1958) Observations on the growth of perch (perca fluvatilis L.) over twenty- two years with special reference to the effects of temperature and changes in population density. J Anim Ecol 27: 287-334.

23. Nikolsky GV (1963) The ecology of fishes. Academic press, London.

24. Qasim SZ (1973) Some implications of the problem of age and growth in marinefishes from the Indian waters. Curr Sci 20: 351-371.

25. Hashem MT (1977) Population characteristics of Bagrus bayad in the Nozhahydrodrome during 1968-1970.
26. El-Badawy AA (1991) Biological study on Some Fishes of High Dam Lake.

27. Mohamed EF (2005) Studies on fishery biology of the Cat fishes (Genus Bagrus) in the River Nile waters of Beni-Suef.

28. Goudswaard PC, Witte F (1997) The catfish fauna of Lake Victoria after the Nile perch upsurge. Environ Biol Fish 49: 21-43.

29. Ogbe FG, Obande RA, Okayi RG (2006) Age, growth and mortality of Bagrus bayad, Macropterus (1775) from Lower Benue River, Nigeria. Biological and Environmental Science Journal for the Tropics 3: 103-109.

30. Imevbore AMA, Bakare O (1970) The food and feeding habits of non-cichlid fishes of the River Niger in the Kainji Reservoir area.

31. Fagade SO, Olaniyan $\mathrm{Cl}$ (1973) The food and feeding interrelationship of the fishes of Lagos Lagoon. J Fish Biol 5: 205-227.

32. Chilvers RM, Gee JM (1974) The food of Bagrus docmac (Forsk) (Pisces: Siluriformes) and its relationship with HaplochromisHilgandorf (Pisces: Cichlidae) in Lake Victoria, East Africa. J Fish Biol 6: 483-505.

33. Sandon H, Tayib AA (1953) The food of some common Nile fish. Sudan Notes and Records 34: 205-229.

34. Petr T (1967) Food preferences of commercial fishes of the Volta Lake.

35. Whyte SA (1975) Distribution, trophic relationships and breeding habits of the fish populations in a tropical lake basin (Lake Bosuntwi-Ghana). J Xool 177: $25-26$

36. Latif AFA (1976) Report on survey to Lake Nasser 